\title{
Bacterial type B RNase P: functional characterization of the L5.1-L15.1 tertiary contact and antisense inhibition
}

\author{
DENNIS WALCZYK, ${ }^{1,3}$ DAGMAR K. WILLKOMM, ${ }^{2,3}$ and ROLAND K. HARTMANN ${ }^{1}$ \\ ${ }^{1}$ Institut für Pharmazeutische Chemie, Philipps-Universität Marburg, D-35037 Marburg, Germany \\ ${ }^{2}$ Klinik für Infektiologie und Mikrobiologie, Universitätsklinikum Schleswig-Holstein Campus Lübeck, D-23538 Lübeck, Germany
}

\begin{abstract}
Ribonuclease $\mathbf{P}$ is the ubiquitous endonuclease that generates the mature $\mathbf{5}^{\prime}$-ends of precursor tRNAs. In bacteria, the enzyme is composed of a catalytic RNA ( $\sim 400$ nucleotides) and a small essential protein subunit ( $13 \mathrm{kDa})$. Most bacterial RNase P RNAs (P RNAs) belong to the architectural type A; type B RNase P RNA is confined to the low-G+C Gram-positive bacteria. Here we demonstrate that the L5.1-L15.1 intradomain contact in the catalytic domain of the prototypic type B RNase P RNA of Bacillus subtilis is crucial for adopting a compact functional conformation: Disruption of the L5.1-L15.1 contact by antisense oligonucleotides or mutation reduced P RNA-alone and holoenzyme activity by one to two orders of magnitude in vitro, largely retarded gel mobility of the RNA and further affected the structure of regions P7/P8/P10.1, P15 and L15.2, and abolished the ability of $B$. subtilis P RNA to complement a P RNA-deficient Escherichia coli strain. We also provide mutational evidence that an L9-P1 tertiary contact, as found in some Mycoplasma type B RNAs, is not formed in canonical type B RNAs as represented by $B$. subtilis P RNA. We finally explored the P5.1 and P15 stem-loop structures as targets for LNA-modified antisense oligonucleotides. Oligonucleotides targeting P15, but not those directed against P5.1, were found to efficiently anneal to P RNA and to inhibit activity ( $\mathrm{IC}_{50}$ of $\sim 2 \mathrm{nM}$ ) when incubated with preassembled $B$. subtilis RNase P holoenzymes.
\end{abstract}

Keywords: $B$. subtilis P RNA; mutation of L5.1-L15.1 contact; structure probing; kinetics; antisense inhibition

\section{INTRODUCTION}

RNase $\mathrm{P}$ endonucleolytically removes 5 '-leader sequences from precursor tRNAs in all domains of life to generate functional tRNAs (Frank and Pace 1998; Lai et al. 2010; Lechner et al. 2015). In bacteria, the RNase P holoenzyme consists of an RNA subunit of up to 400 nucleotides (nt) in length and a small basic protein of $\sim 13 \mathrm{kDa}$ (Kazantsev and Pace 2006). The bacterial RNA subunit displays robust RNA-alone catalytic activity in vitro, but the protein component is indispensable for enzyme function in vivo (Schedl et al. 1974; Kirsebom et al. 1988; Gößringer et al. 2006; for review, see Gösringer and Hartmann 2007). Archaeal and many eukaryotic nuclear RNase P enzymes are ribonucleoprotein (RNP) enzymes as well, but their RNA subunits have lost robust RNA-alone activity (Pannucci et al. 1999; Kikovska et al. 2007; Li et al. 2009, 2011); they depend on more protein subunits (at least four in Archaea, nine to 10 in Eukarya), and none of the archaeal/eukaryal proteins is related to the bacterial RNase P protein (for review, see Hartmann et al. 2009; Ellis and Brown 2010; Jarrous and Gopalan 2010; Lai et al. 2010; Walker et al. 2010; Lechner et al. 2015). Finally, the

\footnotetext{
${ }^{3}$ These authors contributed equally to this work.

Corresponding author: roland.hartmann@staff.uni-marburg.de

Article published online ahead of print. Article and publication date are at http://www.rnajournal.org/cgi/doi/10.1261/rna.057422.116.
}

mammalian mitochondrial RNase P lacks any RNA subunit (Holzmann et al. 2008).

Numerous studies in the bacterial RNase P field contributed novel insights into our general understanding of RNA architecture and structure formation. Milestones included, to name but a few, the finding that RNase P RNAs (P RNAs) consist of two independently folding domains, the specificity (S-) domain and the catalytic (C-) domain (Loria and Pan 1996), the bioinformatic derivation of $\mathrm{P}$ RNA 3D architecture (Massire et al. 1998) and the crystal structures of P RNA domains (Krasilnikov et al. 2003, 2004), full-length P RNAs (Kazantsev et al. 2005; Torres-Larios et al. 2005) and a type A RNase P holoenzyme-tRNA complex (Reiter et al. 2010). There are two architectural types of bacterial P RNA, type A and B (Haas et al. 1996), which differ in peripheral structural elements but have very similar S- and C-domain core structures. However, based on 3D structural analyses, type A RNAs adopt more concave folds (owing to stabilizing interdomain contacts, see below) capable of forming the S-domainT-loop interaction, while the rather flat type B RNA structures

\footnotetext{
(C) 2016 Walczyk et al. This article is distributed exclusively by the RNA Society for the first 12 months after the full-issue publication date (see http://rnajournal.cshlp.org/site/misc/terms.xhtml). After 12 months, it is available under a Creative Commons License (Attribution-NonCommercial 4.0 International), as described at http://creativecommons.org/licenses/bync/4.0/.
} 
need to undergo a conformational change to form the S-domain-T-loop contact (Kazantsev et al. 2011).

In $\mathrm{P}$ RNAs of type $\mathrm{A}$, three interdomain loop-helix contacts are known to orient $\mathrm{C}$ - and S-domains toward each other: L18-P8, L8-P4, and P1-L9 (Brown et al. 1996; Massire et al. 1997, 1998). While the L8-P4 contact is universally conserved among bacterial P RNAs, the L18-P8 interaction is present in most, but not all type A RNAs, and the P1-L9 contact is mainly implemented in thermostable P RNAs of type A (Marszalkowski et al. 2008). Interestingly, two P RNAs from Aquificales with growth optima of $\sim 70^{\circ} \mathrm{C}$ that lack P18 form instead a stable L9-P1 contact consisting of a 5'-GYAA L9 tetraloop docking onto tandem G-C base pairs in P1 (Marszalkowski et al. 2006). The same type of L9-P1 contact likely compensates the lack of P18, and thus absence of the L18-P8 contact in P RNAs from Chlorobium species (Haas et al. 1994). Thus, it seems that usually two interdomain contacts are implemented in bacterial type A RNAs and sometimes three in thermostable P RNAs, such as the one from Thermus thermophilus (Marszalkowski et al. 2008).

In P RNAs of type B, C- and S-domain primarily interact via the conserved L8-P4 contact (Massire et al. 1998; Kazantsev et al. 2005). Regarding P1-L9, it is yet unclear if such contact forms in type B RNA, as the crystal structure of the related Geobacillus stearothermophilus P RNA lacked electron density in the P9 region (Kazantsev et al. 2005). At least a subset of type B RNase P RNAs from Mycoplasma species form a pseudoknot (P21) between an enlarged L9 loop and a single-stranded 3 -extension of P1 (Massire et al. 1997). Within P RNA C-domains, hallmarks are the L5.1L15.1 contact specific for type B and the pseudoknotted P6 helix specific for type A RNAs (Massire et al. 1998).

Several features also make bacterial RNase $\mathrm{P}$ an attractive drug target: (i) The enzyme is essential for viability; (ii) there are fundamental architectural differences between bacterial RNase P and that of eukaryotes; and (iii) at a 60- to 100fold lower copy number in the cell than ribosomes, the number of RNase P molecules to be targeted per cell is comparatively low (Dong et al. 1996). Thus, several studies have so far explored the druggability of bacterial RNase P using different classes of small molecules (Vioque 1989; Mikkelsen et al. 1999; Eubank et al. 2002; Hori et al. 2005; Kawamoto et al. 2008; Toumpeki et al. 2008; Liu et al. 2014; for review, see Willkomm et al. 2010). Finally, as the enzyme mostly consists of RNA, bacterial RNase P lends itself to being addressed by antisense agents. We and others have previously explored antisense inhibition of the type A RNase P RNA from Escherichia coli, which identified the L15/16 loop that interacts with tRNA $3^{\prime}$-CCA ends as the most effective target site within the ribozyme (Childs et al. 2003; Gruegelsiepe et al. 2003, 2006; Willkomm et al. 2003). Noteworthy, conjugates of an invasive peptide and a peptide nucleic acid (PNA) 14-mer targeting the L15/16 loop showed P RNA-specific growth inhibition of E. coli cells (Gruegelsiepe et al. 2006).
Up to now, antisense approaches focused on type A RNase P RNA of E. coli only. However, a number of highly relevant pathogens (e.g., Staphylococcus aureus, B. anthracis, Mycoplasma species) possess type B RNase P RNAs. Therefore, in the present study, we performed experiments to target B. subtilis P RNA as the major model system of type B architecture, although substantial functional and structural studies were also performed with the P RNA from Mycoplasma hyopneumoniae (Svärd et al. 1994, 1996; Brännvall et al. 1998; Brännvall and Kirsebom 2005). We started out with disrupting the tertiary contact between elements L5.1 and L15.1 either via antisense oligonucleotides targeting the L5.1 loop or by mutation, which allowed us to demonstrate the crucial role of this type B-specific interaction for enzyme function in vitro and in vivo. We further compared the L5.1 target region with the L15 loop interacting with tRNA $3^{\prime}$ CCA ends (Svärd et al. 1996; Wegscheid and Hartmann 2007) in terms of inhibitory antisense efficacy. Whereas a 14-meric LNA/DNA mixmer was shown to efficiently target the L15 loop to inhibit activity of B. subtilis RNase P, preassembled holoenzymes were not accessible to invasion and inactivation by even longer LNA-modified oligonucleotides (20- to 21-mers) targeting the L5.1 region. Finally, we could rule out an L9-P1 interdomain contact in B. subtilis RNase $\mathrm{P}$, whose formation had remained unclear because of the lack of electron density in P9 in the X-ray structure of the related Geobacillus stearothermophilus P RNA (Kazantsev et al. 2005).

\section{RESULTS}

\section{Targeting P5.1 of $\boldsymbol{B}$. subtilis P RNA by antisense oligonucleotides}

In an exploratory SELEX procedure to screen for regions in $B$. subtilis P RNA that are accessible to the binding of antisense oligonucleotides (see Supplemental Material; Supplemental Figs. S1, S2), we identified RNA oligonucleotides complementary to sequences in the $\mathrm{P} 5.1$ region (AS1-long and AS2-long), complementary to nt 58-77 and nt 52-72 of $B$. subtilis P RNA, respectively (see Fig. 1A). As these oligonucleotides would disrupt the L5.1-L15.1 tertiary contact in the Cdomain of type B RNase P RNAs (Kazantsev et al. 2005), we decided to analyze this target region in detail. First we addressed the question if the two selected antisense RNAs (AS1-long and AS2-long) targeting the P5.1 region by 20 or 21 complementary nucleotides were able to inhibit the RNase $\mathrm{P}$ reaction. Both oligonucleotides showed inhibitory effects in the RNA-alone reaction (Fig. 1B). As the antisense transcripts contained additional $5^{\prime}$ - and $3^{\prime}$-flanking sequences deriving from the SELEX procedure (see Supplemental Material), we also included a synthetic derivative of library RNA AS1-long that only contained the 20 nt fully complementary to $B$. subtilis RNase P RNA (named AS1). RNA oligonucleotide AS1 was a more effective inhibitor than 
A

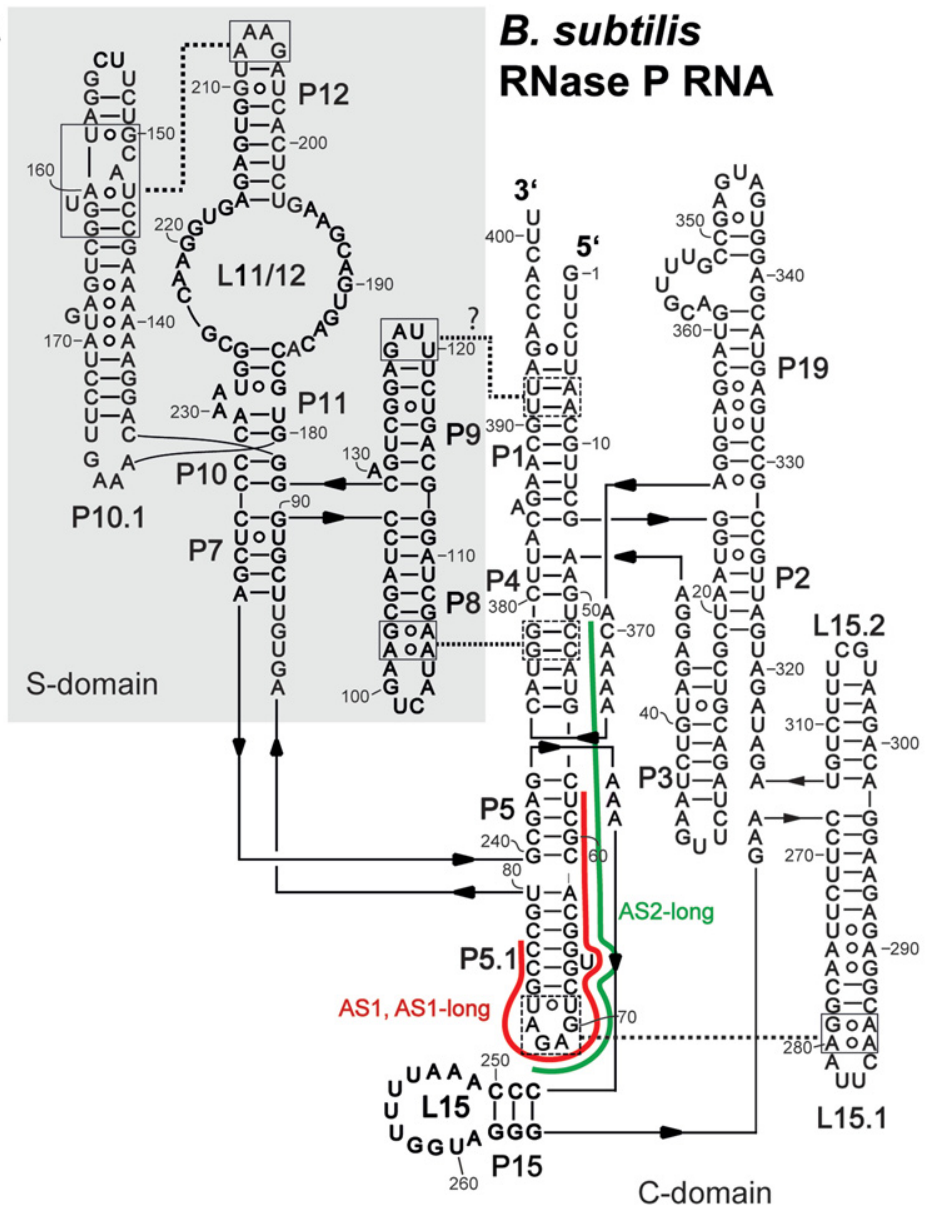

B RNA-alone reaction

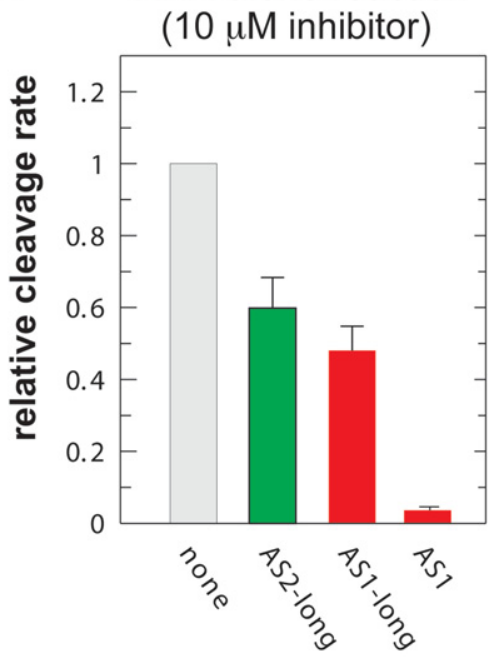

FIGURE 1. (A) Secondary structure of B. subtilis RNase P RNA according to Massire et al. (1998). The S-domain is shown above the gray background; the remainder of the molecule belongs to the $\mathrm{C}$-domain. The complementarity to RNA oligonucleotides targeting the P5.1 region is indicated by the red and green lines along the sequence. Dotted lines indicate long-range tertiary interactions. A possible P1-L9 contact, although unlikely to form based on this study and the lack of phylogenetic evidence (Massire et al. 1997), is marked with a question mark. (B) RNA-alone activity assays for determining the inhibitory effect of antisense RNAs, performed under multiple turnover conditions with $10 \mathrm{nM} P$ RNA and $100 \mathrm{nM}$ pre-tRNA ${ }^{\text {Gly }}$ substrate at $37^{\circ} \mathrm{C}$ (for details, see Materials and Methods). AS1-long and AS2-long are 66-nt-long RNA oligonucleotides with 20 or 21 central nucleotides complementary to B. subtilis P RNA as indicated by the colored lines in panel A (for details, see the Supplemental Material). AS1 lacks the extra $185^{\prime}$-terminal and $283^{\prime}$-terminal nucleotides flanking the $20 \mathrm{P}$ RNA-complementary nucleotides in AS1-long. Values are the mean of five independent experiments each; error bars are standard deviations (SDs).

the parental library RNA AS1-long, suggesting that the additional $5^{\prime}$ - and $3^{\prime}$-flanking sequences negatively affected the efficacy of oligonucleotide annealing. At varying concentrations, RNA oligonucleotide AS1 inhibited RNase P cleavage with an $\mathrm{IC}_{50}$ of $48 \pm 9 \mathrm{nM}$ in the RNA-alone reaction and $89 \pm 51 \mathrm{nM}$ in holoenzyme assay I (Supplemental Fig. S3).

\section{Disrupting the L5.1-L15.1 interaction: effect on P RNA folding}

As RNA antisense oligonucleotides AS1-long and AS2-long were identified in a gel mobility shift-based selection approach (Supplemental Fig. S2), we considered it likely that binding of these RNAs to B. subtilis P RNA, which would disrupt the L5.1-L15.1 long-range interaction (Kazantsev et al. 2005), leads to substantial conformational changes and thus strongly altered gel mobility. To examine this idea, we further constructed a B. subtilis P RNA variant with disrupted L5.1-L15.1 contact owing to truncation of the apical part of L15.1 (named P RNA mutant 115.1 ) (Fig. 2A). The truncation removed the conserved A residues 280, 281, 285, and 286 (Massire et al. 1998) that are crucial for the L5.1-L15.1 interaction (Kazantsev et al. 2005). The shortened stem was closed by a stable $5^{\prime}$-UUCG tetraloop.

Indeed, preannealing of oligonucleotide AS1 to wild-type (wt) P RNA resulted in a substantial retardation of gel mobility (Fig. 2B, lanes 2-4). P RNA variant $\Delta 15.1$ already migrated markedly slower than the wt RNA in the absence of AS1 (Fig. $2 \mathrm{~B}$, lane 5 vs. 1); preannealing of AS1 reduced gel mobility only slightly further (Fig. 2B, lanes 6-8). These findings indicate the fundamental importance of the L5.1-L15.1 contact for the overall folding of bacterial type B RNase P RNAs. 
The effects of disrupting the L5.1-L15.1 contact were also analyzed by RNase T1 probing (Fig. 2C,D). This revealed increased accessibility of L5.1 in the $\Delta 15.1$ mutant (Fig. 2C, G70/72, lanes 5 vs. 4), in line with disruption of the looploop interaction, and confirmed binding of AS1 as predicted. Also, AS1 increased the accessibility of the region $3^{\prime}$ of its binding site (P8/P9/P10.1, Fig. 2A, bottom; Fig. 2C, lane
7 vs. 8) and affected the P15 region: Accessibility of G258/9 decreased and that of G262-265 increased (Fig. 2D, lane 13 vs. lanes 12 and 14), a trend that was also weakly but reproducibly seen for the $\Delta 15.1$ mutant (Fig. 2D, lane 15 vs. 12 and 14). Finally, AS1 and, to a lesser extent, the $\Delta 15.1$ mutation, decreased accessibility of G305 in the L15.2 loop (Fig. 2D, lanes 12-15). In summary, disruption of the L5.1-L15.1
A
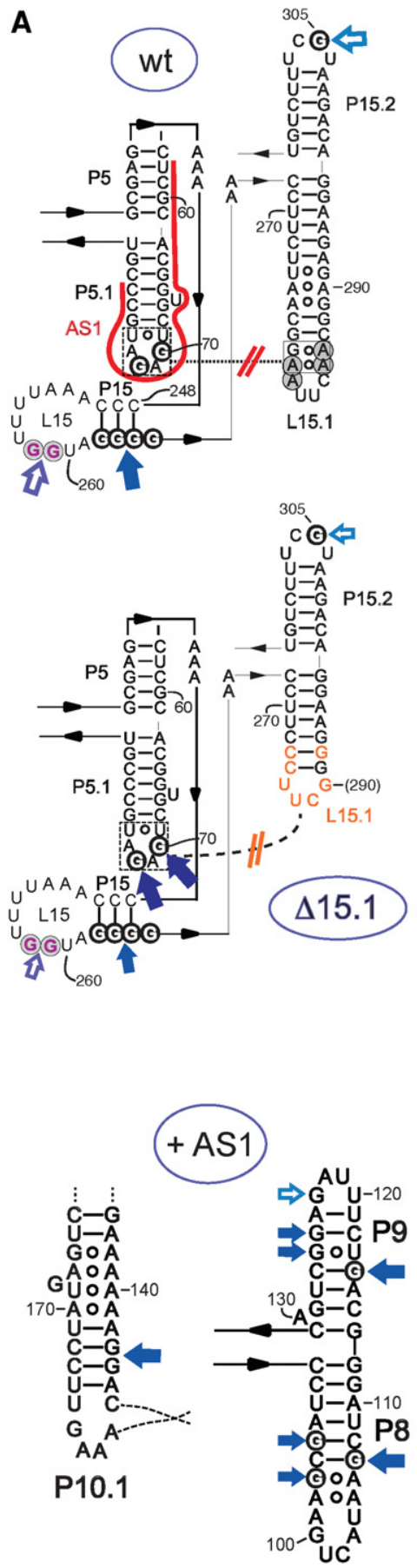

B

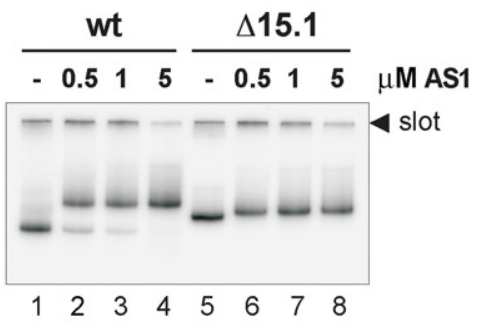

C
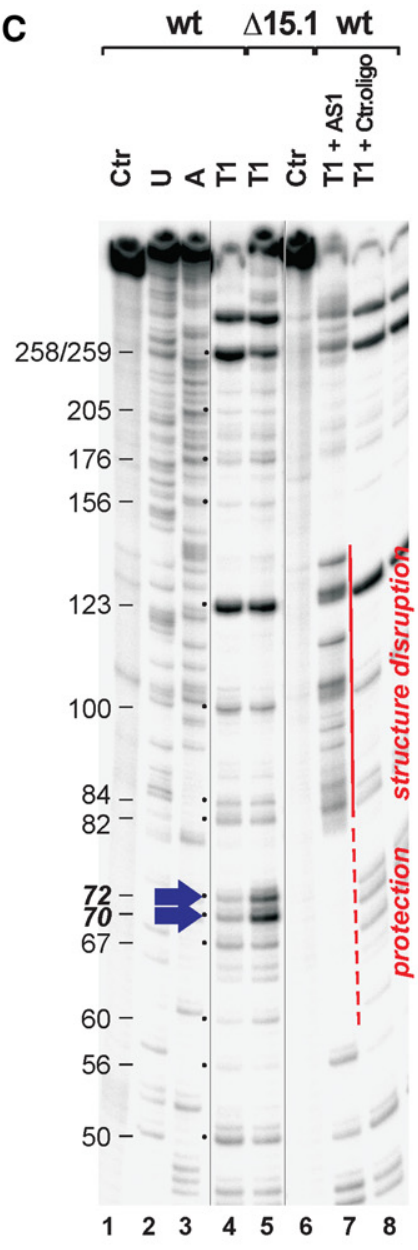

5'-labeled

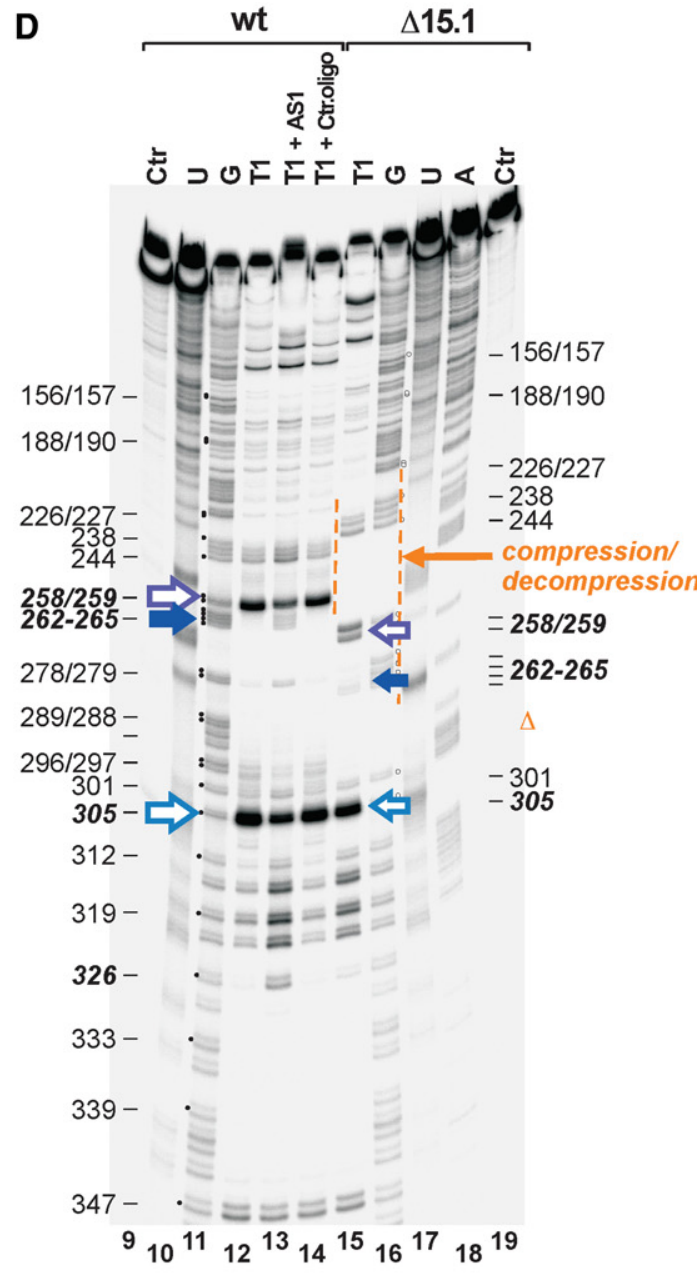

3'-labeled

FIGURE 2. (Legend on next page) 
interaction by annealing of oligonucleotide AS1 altered the accessibility of regions P8/P9/P10.1, P15, and L15.2 to cleavage by RNase T1. Disruption of the interaction by the $\Delta 15.1$ mutation confirmed such an effect for L15.2 (and to a smaller extent for L15) and, as expected, showed increased accessibility also for L5.1.

\section{Kinetic analysis of the P RNA mutants $\Delta 15.1$, $\mathrm{mL9}$, and P9Mf}

In addition to analyzing the effect of disrupting the L5.1L15.1 contact on enzyme activity, we were interested in exploring the possible formation of an L9-P1 tertiary contact. In the X-ray structure of the related G. stearothermophilus P RNA, the apical part of P9 remained unresolved (Kazantsev et al. 2005), but P1 and P9 are juxtaposed and may well interact with each other. To test this, we constructed two P9 mutants of B. subtilis P RNA, variants mL9 and P9Mf (Fig. 3A). In variant $\mathrm{mL}$, the L9 tetraloop was mutated from $5^{\prime}$-UUAG to $5^{\prime}$-GUUU (to disrupt a potential tetraloop sequencespecific interaction), whereas $\mathrm{P} 9$ was largely truncated in variant P9Mf by changing it to the P9 element found in P RNAs from Mycoplasma fermentans and M. flocculare (Massire et al. 1997).

We determined the single turnover kinetic parameters of the RNA-alone reaction $\left(k_{\text {react }}\right.$ and $\left.K_{\mathrm{m}(\text { sto })}\right)$ for $B$. subtilis $\mathrm{P}$ RNAs $\Delta 15.1, \mathrm{~mL}$, and P9Mf relative to the wt RNA (Table 1; Fig. 3B). This revealed essentially no effect of the mL9 mutation, little effect of the P9Mf mutation (less than twofold reduction in $\left.k_{\text {react }} / K_{\mathrm{m}(\text { sto) }}\right)$, but severe defects particularly on the level of $k_{\text {react }}$ in the presence of the $\Delta 15.1$ mutation ( $k_{\text {react }} / K_{\mathrm{m} \text { (sto) }}$ decreased by almost two orders of magnitude) (Table 1). Similarly, the velocity of the holoenzyme reaction was essentially identical for wt P RNA and variants mL9 and
P9Mf, but dropped more than 10-fold in the case of variant $\Delta 15.1$ (Table 2).

\section{In vivo complementation of the $B$. subtilis $\Delta \mathbf{1 5 . 1}$ mutant $P$ RNA in E. coli BW}

Expression of the $\operatorname{rnpB}$ gene (encoding the RNase P RNA subunit) in E. coli strain BW strictly depends on the presence of arabinose in the growth medium (Wegscheid and Hartmann 2006). In the presence of glucose instead of arabinose as the carbon source, chromosomal $\operatorname{rnpB}$ expression is switched off in strain BW and further growth requires (plasmid-based) expression of another gene that provides the RNase $\mathrm{P}$ function. Expression of B. subtilis wt $r n p B$ from plasmid pACYC indeed supported growth of E. coli BW bacteria, although less efficiently than the homologous E. coli rnpB gene (Fig. 4; see the more cauliflower-like appearance of colonies in the upper right segment of the glucose plate). However, no complementation was observed with the $B$. subtilis $\Delta 15.1 \mathrm{rnpB}$ gene (Fig. 4). This in vivo result confirms the in vitro data, indicating that disruption of the L5.1-L15.1 tertiary contact largely prevents type B RNase P RNAs from adopting an active conformation.

\section{Inhibition assays with LNA/RNA(DNA) mixmers}

In our initial inhibition assay (holoenzyme assay I, Supplemental Fig. S3), we preincubated P RNA with the RNA antisense oligonucleotide at $55^{\circ} \mathrm{C}$ before adding the $\mathrm{P}$ protein, which favored oligonucleotide invasion and annealing. We also tested oligonucleotide inhibition in a setup where we preassembled the RNase P holoenzyme before preincubating the holoenzyme and the inhibitory oligonucleotide (holoenzyme assay II). This setup was used in view of applications

\footnotetext{
FIGURE 2. ( $A$, top and middle) Structural environment of P5.1 and P15.1 in B. subtilis wt P RNA and its deletion variant $\Delta 15.1$. The sequence complementary to RNA oligonucleotide AS1 is indicated by the red line adjacent to the wt sequence. Invasion of AS1 disrupts the tertiary contact to L15.1, as indicated by the red double slash. G70, G72, G258, G259, G262-265, and G305 are highlighted, as their susceptibility to RNase T1 cleavage under native conditions (based on the data shown in panels $C$ and $D$ ) was changed upon AS1 hybridization and/or introduction of the $\Delta 15.1$ mutation (indicated by orange lettering), which abrogates the L5.1-L15.1 contact (orange double slash). Filled blue arrows: Increased susceptibility to RNase T1 cleavage in the presence of oligonucleotide or in the $\Delta 15.1$ mutant; open blue arrows: reduced susceptibility to RNase T1 cleavage; arrow size illustrates the relative strength of the effect. G258/259 (highlighted in purple) form Watson-Crick base pairs with pre-tRNA 3'-CCA ends (Wegscheid and Hartmann 2007). (Bottom) Summary of changes in RNase T1 susceptibility in regions P8/P9/P10.1 upon AS1 annealing. (B) Native PAGE analysis of $B$. subtilis wt P RNA and the $\Delta 15.1$ mutant with and without preannealed oligonucleotide AS1. For details, see Materials and Methods. (C,D) Structural probing of $B$. subtilis wt P RNA with or without preannealed RNA oligonucleotide AS1 and of the $\Delta 15.1$ mutant P RNA, either using $(C) 5^{\prime}-{ }^{32} \mathrm{P}$-labeled or $(D) 3^{\prime}-{ }^{32} \mathrm{P}$-labeled RNase P RNA. Ctr, same conditions as for native RNase T1 cleavage, but omission of RNase T1; A, U, iodine cleavage of P RNAs transcribed with trace amounts of aS-ATP and aS-UTP, respectively; T1, limited digestion of P RNA by RNase T1 under native conditions either alone or in the presence of oligonucleotide AS1 or a control RNA 23-mer (5'-CAAGCAGCCUACCAGCUACCUUG-3'; Willkomm et al. 2003) of unrelated sequence (Ctr. oligo); G, cleavage by RNase T1 3' of G residues under denaturing conditions. G residues assigned at the gel margin according to the numbering system of B. subtilis wt P RNA (see Fig. 1) are further marked by a dot next to the corresponding RNase T1 cleavage band. Positions with a marked difference in band intensities between wt P RNA and the mutant and/or in the presence of the RNA oligonucleotide AS1 are highlighted by lettering in bold italics. The red dashed vertical line between lanes 7 and 8 (panel $C$ ) denotes cleavage protection due to oligonucleotide annealing; the orange dashed lines (panel $D$ ) indicate regions of band compression/decompression of the wt versus the mutant P RNA. The orange " $\Delta$ " next to lane 19 indicates the deletion in RNA $\Delta 15.1$. For blue arrows, see legend to panel $A$. The gel images shown in panels $C$ and $D$ are each representative of three independent experiments. Signals at positions 262-265 in lane 15 of panel $D$ were somewhat enhanced in other gels. Comment to lanes 12 and 14 vs. 15 in panel $D$ : The signals corresponding to G258/259 comigrate as a single band in lanes 12 and 14 , but migrate as a doublet in lane 15; phosphoimager quantification of this single band in lanes 12 and 14 gave reproducibly higher signal intensities relative to the doublet signal in lane 15 (normalized to overall radioactivity in each lane).
} 
A

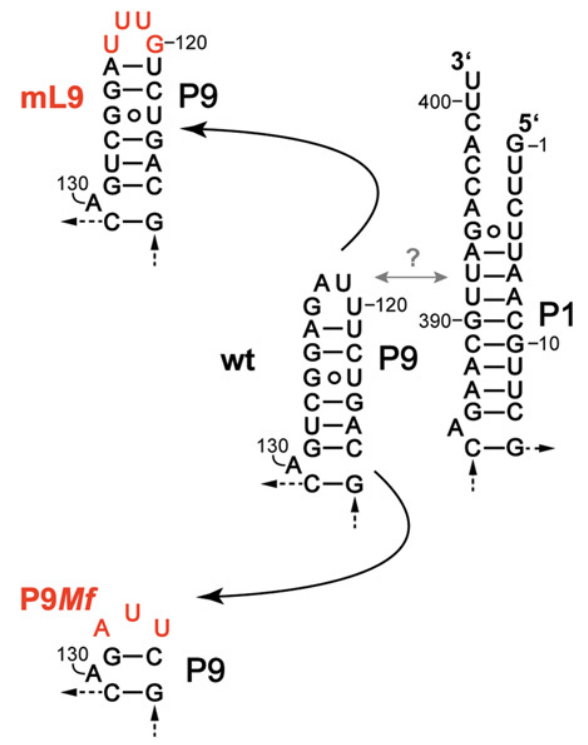

B

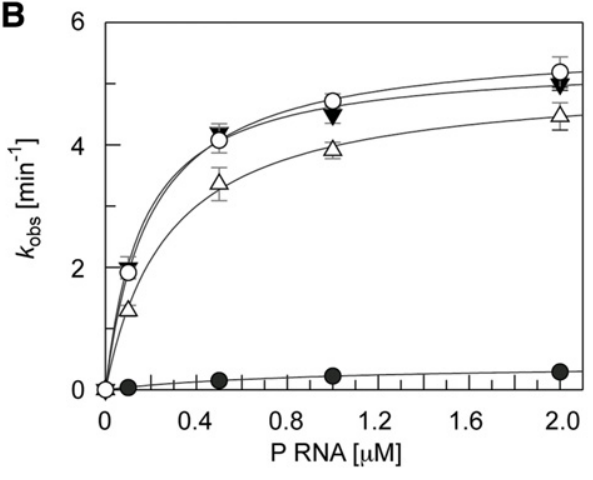

wt $-\mathrm{O}-\quad \Delta 15.1 \multimap-\quad \mathrm{mL9} \rightarrow \boldsymbol{\mathrm { V }} \quad \mathrm{P9Mf} \triangle-$

FIGURE 3. RNA-alone single turnover kinetics of $B$. subtilis wt P RNA and mutant RNAs $\Delta 15.1, \mathrm{~mL}$, and P9Mf. (A) Structural alterations in RNase P RNA variants $\mathrm{mL} 9$ and $\mathrm{P} 9 M$ f relative to the wt RNA (marked by red lettering). In variant $\mathrm{mL} 9$, the $B$. subtilis GNRA P9 tetraloop $5^{\prime}$ UUAG was changed into $5^{\prime}$-GUUU to change the base identity of all four nucleotides. In P9Mf, B. subtilis $\mathrm{P} 9$ was truncated to the shortened P9 version naturally occurring in P RNAs of Mycoplasma fermentans and $M$. flocculare, expected to be unable to form any P9-P1 interaction because of being too short. (B) Curve fits of single turnover kinetic experiments (RNA-alone reaction) to determine the kinetic parameters $k_{\text {react }}$ and $K_{\mathrm{m}(\text { sto })}$ of $B$. subtilis wt P RNA and variants $\Delta 15.1, \mathrm{~mL} 9$, and $\mathrm{P} 9 M f$ (see Table 1). The data are based on at least three independent experiments; error bars are standard deviations of the mean (SEM).

closer to the natural situation (where inhibitors primarily act on assembled holoenzymes), e.g., where one wants to inhibit endogenous RNase $\mathrm{P}$ activities in cell lysates in the context of RNA processing studies. Under these conditions, we did not observe any significant inhibition by RNA oligonucleotide AS1 at a concentration of $10 \mu \mathrm{M}$, irrespective of the length $(5-30 \mathrm{~min})$ and temperature $\left(37^{\circ} \mathrm{C}\right.$ or $\left.50^{\circ} \mathrm{C}\right)$ of holoenzyme/inhibitor preincubation before addition of pre-tRNA (Fig. 5B,C). To enhance inhibition efficacy, we then tested an LNA/RNA mixmer version of AS1 (named AS1-LNA) and another LNA/RNA mixmer with the target site on $\mathrm{P}$ RNA shifted by $7 \mathrm{nt}$ and $1 \mathrm{nt}$ longer than AS1 (named AS3-LNA). AS1-LNA showed enhanced inhibition in the $50^{\circ} \mathrm{C}$ preincubation setup only (relative to AS1), while AS3LNA failed to substantially improve efficacy (Fig. 5B,C). To further enhance inhibition efficacy, we considered the L15 loop as a target site, based on its exposition on the surface for Watson-Crick binding with pre-tRNA $3^{\prime}$-CCA ends (Svärd et al. 1996; Wegscheid and Hartmann 2007) and the suitability of the corresponding region in type A RNAs for antisense inhibition (Gruegelsiepe et al. 2003, 2006; Willkomm et al. 2003). The 14-meric LNA/DNA mixmer AS4LNA (directed against nt 251-264 of P15) indeed turned out to be an efficient inhibitor of the B. subtilis RNase P holoenzyme, strongly inhibiting enzyme activity in the $37^{\circ} \mathrm{C}$ and $50^{\circ} \mathrm{C}$ preincubation setup and after preincubation periods as short as 5 min (Fig. $5 \mathrm{~B}, \mathrm{C}$ ), with an $\mathrm{IC}_{50}$ of $\sim 2 \mathrm{nM}$ (holoenzyme/inhibitor preincubation for $15 \mathrm{~min}$ at $37^{\circ} \mathrm{C}$ ) (Fig. 6).

\section{DISCUSSION}

Disrupting the L5.1-15.1 tertiary contact of B. subtilis P RNA by an antisense RNA oligonucleotide annealing to the P5.1/ P5 region or by deleting the apical part of L15.1 substantially reduced the RNA's three-dimensional compactness, as inferred from largely retarded mobility in native PAA gels. The change in gel mobility relative to native P RNA was particularly pronounced upon annealing of the antisense RNA 20-mer, explaining why we identified this type of antisense oligonucleotides in a SELEX assay selecting for antisense RNAs that retard P RNA gel mobility. RNase T1 probing indicated that disruption of the L5.1-15.1 interaction also affects folding of the nearby P15 element, known to interact with tRNA 3'-CCA ends (Figs. 2, 7). The sensitivity of the L15 loop to changes induced by structural alterations in its vicinity may be explained by its high flexibility, inferred from the finding that it remained unresolved in the G. stearothermophilus P RNA crystal structure (Kazantsev et al. 2005). Altered susceptibility at G305 in the L15.2 loop upon L5.1-15.1 disruption was surprising, as P15.2 sticks out of the molecule and points to the opposite direction relative to P15.1 (Fig. 7). This may reflect a more indirect effect

TABLE 1. Single turnover kinetic parameters of $B$. subtilis P RNA variants (RNA-alone reaction)

\begin{tabular}{lclc}
\hline P RNA & $K_{\text {react }}\left(\mathrm{min}^{-1}\right)$ & \multicolumn{1}{c}{$K_{\mathrm{m}(\text { sto })}(\mu \mathrm{M})$} & $K_{\text {react }} / K_{\mathrm{m} \text { (sto) }}\left(\mathrm{M}^{-1} \mathrm{~s}^{-1}\right)$ \\
\hline $\mathrm{wt}$ & $5.7 \pm 0.02$ & $0.20 \pm 0.004$ & $0.47 \times 10^{6}$ \\
$\mathrm{~mL} 9$ & $5.4 \pm 0.13$ & $0.16 \pm 0.02$ & $0.56 \times 10^{6}$ \\
P9Mf & $5.1 \pm 0.11$ & $0.28 \pm 0.02$ & $0.30 \times 10^{6}$ \\
$\Delta 15.1$ & $0.43 \pm 0.01$ & $0.96 \pm 0.05$ & $0.75 \times 10^{4}$ \\
\hline
\end{tabular}

For details, see Materials and Methods; $k_{\text {react }}$ and $K_{\mathrm{m}(\mathrm{sto})}$ values are mean values from at least three independent experiments; errors are standard errors of the curve fit. 
TABLE 2. Holoenzyme reactions for wt B. subtilis $\mathrm{P}$ RNA and mutants thereof

\begin{tabular}{lcc}
\hline & \multicolumn{2}{c}{$k_{\text {obs }}\left(\mathrm{min}^{-1}\right)$} \\
\hline RNA & P protein & Without protein \\
\hline wt & $25 \pm 9$ & $0.005 \pm 0.001$ \\
mL9 & $29 \pm 14$ & $0.005 \pm 0.001$ \\
P9Mf & $28 \pm 13$ & $0.004 \pm 0.001$ \\
$\Delta 15.1$ & $2.1 \pm 0.3$ & $0.001 \pm 0.000$ \\
no RNA & - & -
\end{tabular}

Reactions were performed as described in Materials and Methods. Preincubations and holoenzyme assembly were performed according to holoenzyme assay I conditions; $k_{\text {obs }}$ values are mean values from at least three independent experiments $( \pm \mathrm{SD})$.

resulting from altered interaction modes of P RNA and the relatively bulky RNase T1 probe upon disruption of the L5.1-15.1 tertiary contact. However, one should mention that the genuine positioning of P15.2 is not yet clear, since the L15.2 loop was involved in the formation of crystal contacts (Kazantsev et al. 2005). Oligonucleotide invasion into P5.1/P5 further seemed to destabilize folding of elements $\mathrm{P} 7 / \mathrm{P} 8 / \mathrm{P} 10.1$, as inferred from increased susceptibility to hydrolysis by RNase T1 (Fig. 2).

Combined with the kinetic data and in vivo complementation results obtained for the P RNA variant $\Delta 15.1$, our findings demonstrate that the L5.1-15.1 intra-C-domain contact is a key strut of the type B structure, required for locking the RNA in its active conformation, which likely also positions the neighboring L15 in a manner favorable for base-pairing with pre-tRNA $3^{\prime}$-CCA ends. Architecturally, the L5.1-15.1 intra-C-domain contact is likely at least as crucial as the universally conserved L8-P4 interdomain contact, as the L5.115.1 contact is a lateral clamp with optimal leverage effect, apparently well placed to effectively stabilize the rather flat array of helical domains in type B catalytic RNAs (Fig. 7; Kazantsev et al. 2005).

Both the L5.1-15.1 and L8-P4 contacts were found to be surprisingly complex in the crystal structure of $G$. stearothermophilus P RNA (Kazantsev et al. 2005). This complexity of the L5.1-15.1 interaction may explain its relative inaccessibility to oligonucleotide invasion in the context of the fully assembled holoenzyme (Fig. 5). Our study further excludes formation of a specific L9-P1 tertiary contact that may significantly contribute to interdomain orientation and catalytic function in normal type B RNase P RNAs. Only some Mycoplasma type B RNase P RNAs have developed a tertiary contact between L9 and P1, in this case a pseudoknot interaction (P21; see above). Why some Mycoplasma species (M. genitalium, M. pneumoniae) have this stabilizing L9-P1 contact which is lacking in others remains to be addressed experimentally.

The 20-meric RNA oligonucleotide AS1, a derivative of the selected library RNA AS1-long, was only weakly inhibitory in assays using the preassembled RNase P holoenzyme. To improve oligonucleotide affinity and thus inhibition efficacy, we designed two RNA/LNA mixmers (AS1-LNA and AS3-LNA) that differed from each other by somewhat shifted target sites. Both mixmers did not substantially improve the efficacy of inhibition when preincubated with the RNase P holoenzyme at $37^{\circ} \mathrm{C}$. Increasing the temperature for preincubation of holoenzyme and oligonucleotide to $50^{\circ} \mathrm{C}$ to enhance flexibility of the P RNA structure and facilitate oligonucleotide invasion, marginally enhanced inhibition by AS3-LNA and moderately by AS1-LNA. Temperatures $>50^{\circ} \mathrm{C}$ were not used to avoid disassembly of the holoenzyme. However, a 14-meric LNA/DNA mixmer (AS4-LNA) directed against the P15 element turned out to be a very efficient inhibitor of the B. subtilis RNase P holoenzyme, in line with exposure of the L15 loop on the RNA's surface for base-pairing with tRNA 3'-CCA ends. The AS4-LNA inhibitor may be useful to block the endogenous RNase P activity in cell lysates used for RNA processing studies employing exogenously added RNases. For example, B. subtilis cells grown under heat shock conditions (e.g., $50^{\circ} \mathrm{C}$ ) may accumulate RNA precursors for which processing may subsequently be analyzed in cell lysates after silencing of endogenous RNase P activity.

Our finding that the L15 loop is an excellent target site for antisense strategies not only in bacterial type A RNase P RNAs (Childs et al. 2003; Gruegelsiepe et al. 2003, 2006; Willkomm et al. 2003), but also in type B RNAs (this study), allows one to conclude that this region is generally predestined for antisense inhibition strategies, thus obviating the need for experimental approaches to screen for accessible regions in other bacterial P RNAs. Furthermore, in addition to sterically interfering with substrate ( $3^{\prime}$-CCA) binding, the inhibitory efficacy of antisense oligonucleotides targeting the

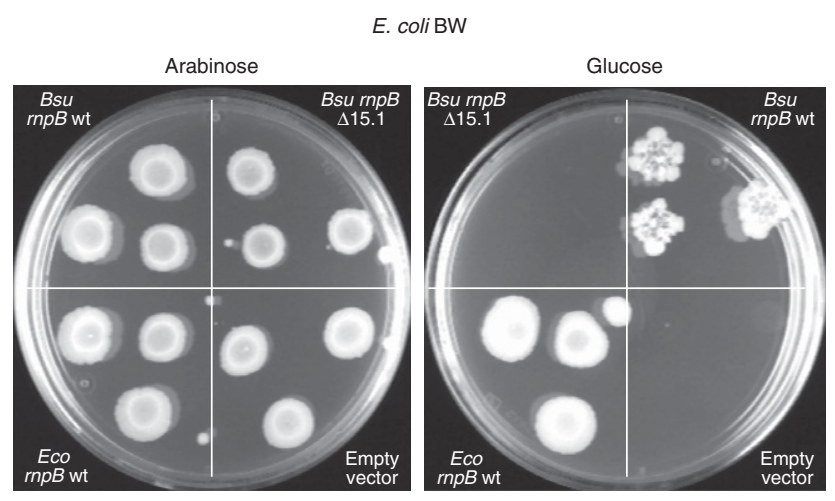

FIGURE 4. LB agar plates with E. coli BW cells transformed with the empty expression vector $\mathrm{pACYC}$ or the same plasmid harboring the native E. coli $r p p B$ gene, or the structural gene encoding B. subtilis wt or $\triangle 15.1$ P RNA, each fused to the $E$. coli $r n p B$ promoter. Cells were grown for $2 \mathrm{~d}$ under permissive (arabinose) or nonpermissive (glucose) conditions at $37^{\circ} \mathrm{C}$. The more cauliflower-like colony appearance of BW cells expressing B. subtilis $r p p B$ under glucose conditions can be attributed to slower colony growth (less efficient complementation). For further details, see Materials and Methods. 
A

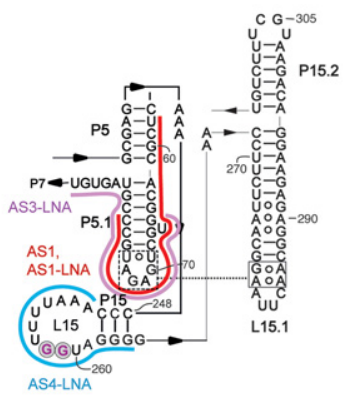

B
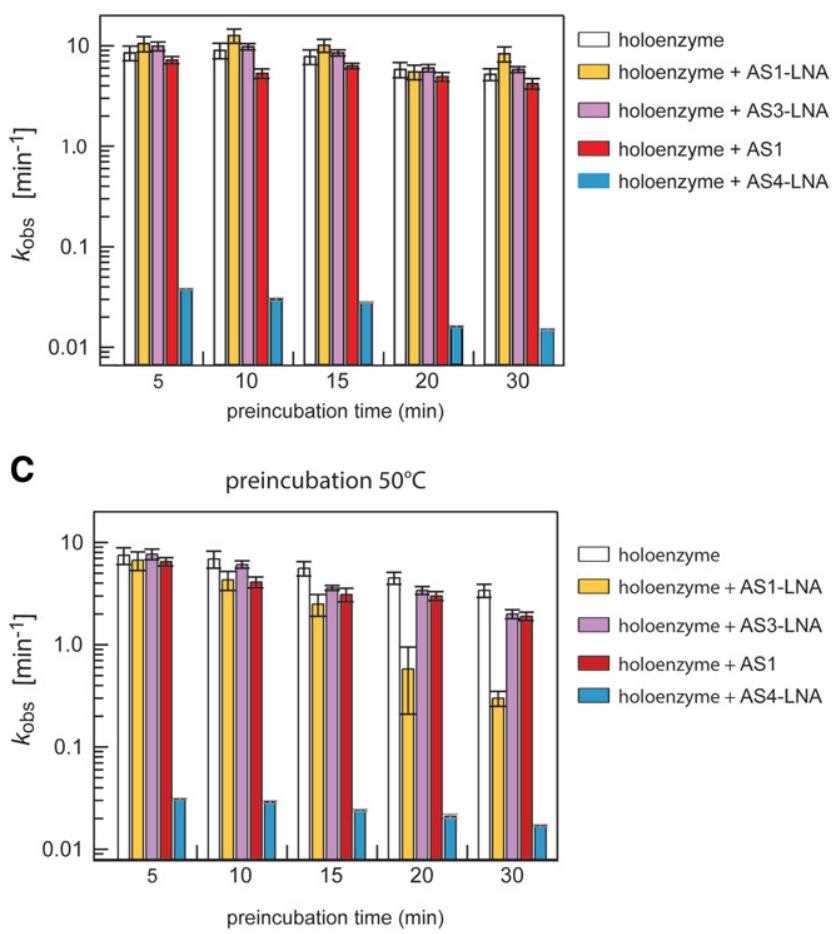

FIGURE 5. Oligonucleotide inhibition of preformed B. subtilis RNase $\mathrm{P}$ holoenzymes (holoenzyme assay II, see Materials and Methods) acting on pre-tRNA ${ }^{\text {Gly }}$ as substrate. (A) Target regions of the RNA oligonucleotides in B. subtilis P RNA (for details on oligonucleotide sequence and modification, see Materials and Methods). G258/259 (highlighted in purple) form Watson-Crick base pairs with pre-tRNA $3^{\prime}$-CCA ends (Wegscheid and Hartmann 2007). (B,C) Processing activity $\left(k_{\text {obs }}\right)$ after preincubation of holoenzyme and oligonucleotide at $37^{\circ} \mathrm{C}(B)$ or $50^{\circ} \mathrm{C}$ (C) for 5, 10, 15, 20 or $30 \mathrm{~min}$. The data are based on three independent experiments; error bars are standard deviations of the mean (SEM).

L15 loop of E. coli (type A) RNase P RNAs was inferred to include contributions from partially unfolding the catalytic core and from perturbing the coordination of catalytically relevant $\mathrm{Mg}^{2+}$ ions (Gruegelsiepe et al. 2006). It will be interesting to explore to which extent this mechanistically applies to bacterial type B RNase P enzymes as well. Finally, peptide nucleic acid (PNA) versions of the AS4 oligonucleotide coupled to invasive peptides are promising candidates for in vivo growth inhibition of $B$. subtilis, as demonstrated for PNA-peptide conjugates targeting the functionally equivalent L15 loop region of E. coli RNase P RNA (Gruegelsiepe et al. 2006). Even further, the L15 loop due to both accessibility and key role in RNase P function lends itself to be explored as a potentially vulnerable target site also for RNase $\mathrm{P}$ inhibitors of other chemical natures for which an in vivo application might be more feasible than for antisense oligonucleotide-based strategies.

\section{MATERIALS AND METHODS}

\section{Synthetic oligonucleotides}

The RNA oligonucleotide AS1 (5'-GGCAUCUCAGCACCGUGC GA-3'; targeting nt 58-77 of B. subtilis P RNA), lacking the constant $5^{\prime}$ - and $3^{\prime}$-extensions of the SELEX library transcripts (see Supplemental Material), was obtained from Integrated DNA Technologies (IDT). LNA/RNA mixmers AS1-LNA (5'-GGCAUCUCAGCACC GUGCGA-3'; as AS1, but with locked nucleic acid [LNA] modifications indicated in bold) and AS3-LNA (5'-ACACUACGGGCAUC UCAGCAC-3', targeting nt 85-65 of B. subtilis P RNA, LNA modifications indicated in bold), as well as the LNA/DNA mixmer AS4-LNA (5'-CCCTACCAAAATTT-3', targeting nt 264-251 of B. subtilis P RNA, LNA modifications indicated in bold) were purchased from Exiqon.

\section{Construction of mutant P RNAs}

Transcription templates for mutant P RNAs were constructed using standard PCR techniques as described in Li et al. (2009) and verified by DNA dideoxy sequencing (custom service by Eurofins Genomics).

\section{Inhibition assays}

All inhibition assays were performed under multiple turnover conditions (10 nM P RNA and $100 \mathrm{nM}$ pre-tRNA substrate).

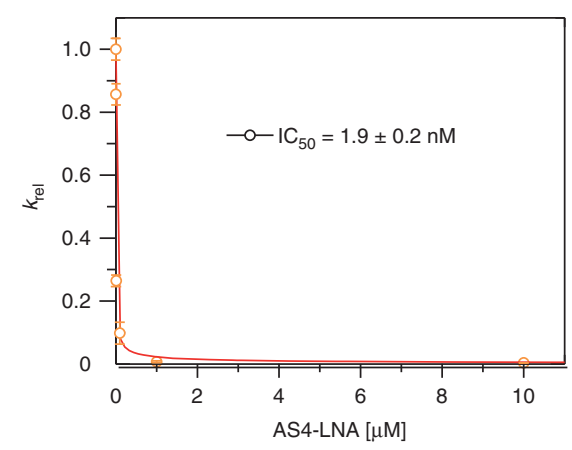

FIGURE 6. Normalized rate $\left(k_{\text {rel }}=\right.$ ratio of rate for the inhibited reaction divided by that for the uninhibited reaction) of pre-tRNA ${ }^{\text {Gly }}$ cleavage by the preassembled B. subtilis RNase $\mathrm{P}$ holoenzyme as a function of the concentration of the LNA/DNA mixmer AS4-LNA. Holoenzyme and inhibitor were preincubated for $15 \mathrm{~min}$ at $37^{\circ} \mathrm{C}$ before substrate addition. $\mathrm{IC}_{50}( \pm$ standard error of the fit) indicates the oligonucleotide concentration at which the cleavage rate reached $50 \%$ of rate for the uninhibited reaction. The data are based on at least three independent experiments; error bars are SEMs. For data fitting to obtain $k_{\text {rel }}$, see legend to Supplemental Figure S3. 


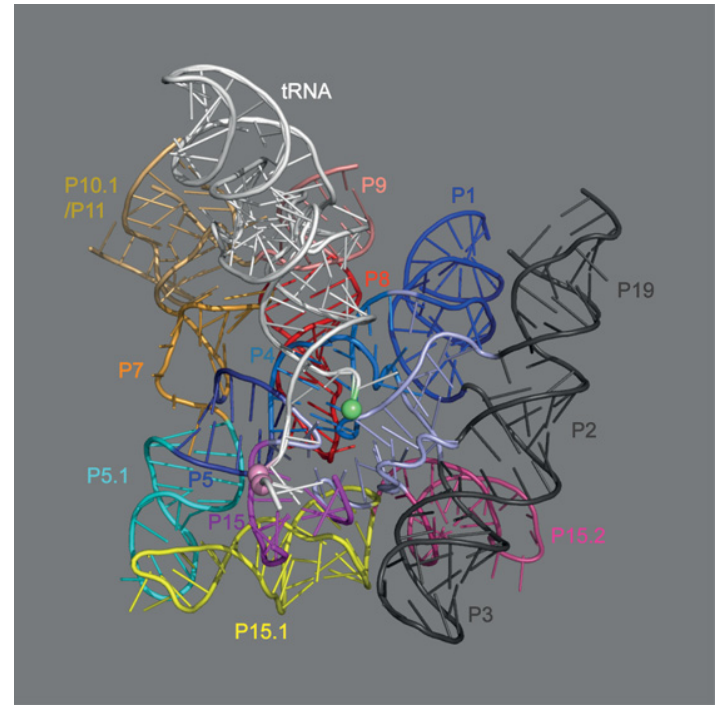

FIGURE 7. Tertiary structure model of G. stearothermophilus type B RNase P RNA (Kazantsev et al. 2005) in complex with tRNA ${ }^{\text {Phe }}$ (Buck et al. 2005) to illustrate the architectural role of the L5.1-L15.1 contact and its vicinity to the L15 loop interacting with C74 and C75 of tRNA $3^{\prime}$ ends (highlighted as pink spheres). The green sphere marks the $5^{\prime}$-terminal nucleotide of mature tRNA.

Preincubation of pre-tRNA in RNA-alone reactions was for $5 \mathrm{~min}$ at $55^{\circ} \mathrm{C}$ and for $25 \mathrm{~min}$ at $37^{\circ} \mathrm{C}$; P RNAs were preincubated with inhibitor for $40 \mathrm{~min}$ at $37^{\circ} \mathrm{C}$ in reaction buffer [ $100 \mathrm{mM} \mathrm{Mg}(\mathrm{OAc})_{2}, 100$ $\mathrm{mM} \mathrm{NH} \mathrm{H}_{4} \mathrm{OAc}$ and $50 \mathrm{mM}$ HEPES, $\mathrm{pH}$ 7.0]. RNase P holoenzyme reactions were performed in buffer $\mathrm{KN}$ (200 mM HEPES, pH 7.4, $150 \mathrm{mM} \mathrm{NH}_{4} \mathrm{OAc}, 2 \mathrm{mM}$ spermidine, $0.05 \mathrm{mM}$ spermine, $4 \mathrm{mM}$ $\beta$-mercaptoethanol) and $4.5 \mathrm{mM} \mathrm{Mg}(\mathrm{OAc})_{2}$.

For holoenzyme assay I, P RNA and inhibitor were preincubated for $5 \mathrm{~min}$ at $55^{\circ} \mathrm{C}$ followed by $50 \mathrm{~min}$ at $37^{\circ} \mathrm{C}$. Then RNase P protein was added, followed by another $5 \mathrm{~min}$ at $37^{\circ} \mathrm{C}$. Pre-tRNA was preincubated for $5 \mathrm{~min}$ at $55^{\circ} \mathrm{C}$ and for $25 \mathrm{~min}$ at $37^{\circ} \mathrm{C}$.

For holoenzyme assay II, preassembled holoenzyme was used and preincubated with inhibitor for 5 to $30 \mathrm{~min}$ at $37^{\circ} \mathrm{C}$ or $50^{\circ} \mathrm{C}$. PretRNA was incubated at $85^{\circ} \mathrm{C}$ for $2 \mathrm{~min}$ in $\mathrm{KN}$ buffer without $\mathrm{Mg}^{2+}$, then chilled on ice, followed by adding $\mathrm{Mg}(\mathrm{OAc})_{2}$ to a final concentration of $4.5 \mathrm{mM}$. Holoenzyme assembly was carried out as follows: $10 \mathrm{nM} \mathrm{B}$. subtilis P RNA was incubated in KN buffer for $1 \mathrm{~min}$ at $85^{\circ} \mathrm{C}$ and cooled down to room temperature within 1 h. Samples were then adjusted to $4.5 \mathrm{mM} \mathrm{Mg}(\mathrm{OAc})_{2}$ and incubated for $5 \mathrm{~min}$ at $37^{\circ} \mathrm{C}$. Holoenzyme formation was induced by addition of $B$. subtilis $\mathrm{P}$ protein ( $20 \mathrm{nM}$ final concentration), followed by incubation for $10 \mathrm{~min}$ at $37^{\circ} \mathrm{C}$. Holoenzyme aliquots were frozen in liquid nitrogen, stored at $-80^{\circ} \mathrm{C}$, and used up (leftovers discarded) after the first thawing. For the number of individual experiments and experimental errors, see figure and table legends.

\section{In vitro transcription, ${ }^{32} \mathrm{P}$-labeling, and structure probing with RNase T1}

B. subtilis P RNA variants and pre-tRNA ${ }^{\text {Gly }}$ (from T. thermophilus) were produced by runoff in vitro transcription using plasmid pDW66 and mutant constructs thereof (linearized with DraI; Warnecke et al. 1999), and pSBpt3'hh (linearized with BamHI;
Busch et al. 2000), respectively, as previously described (Gruegelsiepe et al. 2005). 5'-End-labeling of pre-tRNA and $5^{\prime}$ and $3^{\prime}$-end-labeling of P RNAs were done as previously described (Gimple and Schön 2014). Enzymatic probing with RNase T1 was performed according to Li et al. (2009). For the synthesis of partially Rp-phosphorothioate-modified P RNAs and generation of phosphorothioate-specific iodine hydrolysis ladders, see Heide et al. (2001).

\section{Native PAGE analysis}

Native PAGE analysis of $B$. subtilis wt P RNA and the $\Delta 15.1$ mutant with and without preannealed oligonucleotide AS1 was performed as follows: $20,000 \mathrm{cpm}$ of $3^{\prime}-{ }^{32} \mathrm{P}$-labeled P RNA plus $50 \mathrm{fmol} \mathrm{AS1}$ were preincubated in buffer $\mathrm{KN}$ containing $4.5 \mathrm{mM} \mathrm{Mg}(\mathrm{OAc})_{2}$ for $5 \mathrm{~min}$ at $55^{\circ} \mathrm{C}$ plus $50 \mathrm{~min}$ at $37^{\circ} \mathrm{C}$, followed by mixing with an equal volume of native gel loading buffer (10\% glycerol, $0.025 \%$ each xylene cyanol and bromophenol blue, $10 \mathrm{mM} \mathrm{MgCl}_{2}$ ) and native $11.25 \%$ polyacrylamide gel electrophoresis in THEAM buffer (66 mM HEPES, 33 mM Tris-HCl, 1 mM EDTA, $100 \mathrm{mM}$ $\mathrm{NH}_{4} \mathrm{OAc}$, and $10 \mathrm{mM} \mathrm{MgCl}_{2}, \mathrm{pH}$ 7.4).

\section{Preparation of recombinant RNase P protein}

Recombinant RNase P protein used for holoenzyme assay I was prepared as previously described (Marszalkowski et al. 2006), and for holoenzyme assay II according to Niranjanakumari et al. (1998).

\section{Single turnover RNA-alone kinetics of $B$. subtilis P RNA variants}

Reactions were carried out in $50 \mathrm{mM}$ MES, $100 \mathrm{mM} \mathrm{Mg}(\mathrm{OAc})_{2}$, $100 \mathrm{mM} \mathrm{NH}_{4} \mathrm{OAc}, 0.1 \mathrm{mM}$ EDTA, $\mathrm{pH}$ 6.0, using trace amounts $(<1 \mathrm{nM})$ of $5^{\prime}-{ }^{32} \mathrm{P}$-end-labeled pre-tRNA ${ }^{\text {Gly }}$ (the $3^{\prime}$-CCA terminus extended by the trinucleotide GUC) and varying excess amounts of the respective $B$. subtilis P RNA variant. Substrate and P RNA were preincubated separately in the same buffer for $5 \mathrm{~min}$ at $55^{\circ} \mathrm{C}$ and $55 \mathrm{~min}$ at $37^{\circ} \mathrm{C}$ before mixing the two to start the kinetics at $37^{\circ} \mathrm{C}$. Aliquots were withdrawn at different time points, reactions stopped by addition of denaturing loading buffer, and samples analyzed by $20 \%$ denaturing PAGE. The single turnover kinetic parameters $k_{\text {react }}$ and $K_{\mathrm{m} \text { (sto) }}$ shown in Table 1 were determined as described in Busch et al. (2000). For the number of individual experiments and experimental errors, see figure and table legends.

\section{Holoenzyme kinetics of $B$. subtilis P RNA variants}

Reactions were performed with holoenzyme preassembled from $10 \mathrm{nM}$ RNase P RNA and $100 \mathrm{nM}$ B. subtilis RNase P protein using $100 \mathrm{nM} 5^{\prime}-{ }^{32} \mathrm{P}$-end-labeled pre-tRNA ${ }^{\text {Gly }}$ in buffer KN4.5 (20 mM HEPES, pH $7.4\left[37^{\circ} \mathrm{C}\right], 150 \mathrm{mM} \mathrm{NH}_{4} \mathrm{OAc}, 2 \mathrm{mM}$ spermidine, $0.05 \mathrm{mM}$ spermine, $4 \mathrm{mM} \beta$-mercaptoethanol, $4.5 \mathrm{mM}$ $\mathrm{Mg}[\mathrm{OAc}]_{2}$ ) at $37^{\circ} \mathrm{C}$. For the number of individual experiments and experimental errors, see figure and table legends.

\section{In vivo complementation analysis}

The E. coli BW strain carries the chromosomal rnpB gene under control of the arabinose-dependent $\mathrm{P}_{\mathrm{BAD}}$ promoter (Wegscheid and 
Hartmann 2006). Bacteria were chemically transformed with the low copy vector pACYC encoding the respective $r m p B$ structural gene under control of the native E. coli r $n p B$ promoter. For complementation experiments, a single colony was resuspended in $500 \mu \mathrm{L}$ LB medium. A droplet of $10 \mu \mathrm{L}$ was applied to an LB agar plate containing $100 \mu \mathrm{g} / \mathrm{mL}$ ampicilin, $34 \mu \mathrm{g} / \mathrm{mL}$ chloramphenicol, and $10 \mathrm{mM}$ arabinose or glucose. Plates were incubated for $2 \mathrm{~d}$ at $37^{\circ} \mathrm{C}$.

\section{SUPPLEMENTAL MATERIAL}

Supplemental material is available for this article.

\section{ACKNOWLEDGMENTS}

We would like to acknowledge Heike Wünnenberg (née Gruegelsiepe), Martin Lützelberger, Jørgen Kjems, and Ina Hagedorn for their experimental and technical contributions to the SELEX experiments, and Ina Hagedorn also for contributing to the initial kinetic experiments. We thank the German Research Foundation (DFG) (grants HA 1672/17-1 and GRK 1384) for funding.

Received May 10, 2016; accepted August 6, 2016.

\section{REFERENCES}

Brännvall M, Kirsebom LA. 2005. Complexity in orchestration of chemical groups near different cleavage sites in RNase P RNA mediated cleavage. J Mol Biol 351: 251-257.

Brännvall M, Mattsson JG, Svärd SG, Kirsebom LA. 1998. RNase P RNA structure and cleavage reflect the primary structure of tRNA genes. J Mol Biol 283: 771-783.

Brown JW, Nolan JM, Haas ES, Rubio MA, Major F, Pace NR. 1996. Comparative analysis of ribonuclease P RNA using gene sequences from natural microbial populations reveals tertiary structural elements. Proc Natl Acad Sci 93: 3001-3006.

Buck AH, Kazantsev AV, Dalby AB, Pace NR. 2005. Structural perspective on the activation of RNase P RNA by protein. Nat Struct Mol Biol 12: $958-964$.

Busch S, Kirsebom LA, Notbohm H, Hartmann RK. 2000. Differential role of the intermolecular base pairs G292-C(75) and G293-C(74) in the reaction catalyzed by Escherichia coli RNase P RNA. J Mol Biol. 299: 941-951.

Childs JL, Poole AW, Turner DH. 2003. Inhibition of Escherichia coli RNase P by oligonucleotide directed misfolding of RNA. RNA 9: 1437-1445.

Ellis JC, Brown JW. 2010. The evolution of RNase P and its RNA. In Ribonuclease P (ed. Liu F, Altman S), pp. 17-40. Springer, New York.

Eubank TD, Biswas R, Jovanovic M, Litovchick A, Lapidot A, Gopalan V. 2002. Inhibition of bacterial RNase P by aminoglycoside-arginine conjugates. FEBS Lett 511: 107-112.

Dong H, Kirsebom LA, Nilsson L. 1996. Growth rate regulation of 4.5 S RNA and M1 RNA the catalytic subunit of Escherichia coli RNase P. J Mol Biol 261: 303-308.

Frank DN, Pace NR. 1998. Ribonuclease P: unity and diversity in a tRNA processing ribozyme. Annu Rev Biochem 67: 153-180.

Gimple O, Schön A. 2014. Direct determination of RNA sequence and modification by radiolabeling methods. In Handbook of RNA Biochemistry, 2nd ed. (ed. Hartmann RK, et al.), pp. 175-204. Wiley-VCH Verlag GmbH \& Co. KGaA, Weinheim, Germany.

Gößringer M, Kretschmer-Kazemi Far R, Hartmann RK. 2006. Analysis of RNase P protein (rnpA) expression in Bacillus subtilis utilizing strains with suppressable rnpA expression. J Bacteriol 188: 68166823.
Gösringer M, Hartmann RK. 2007. Function of heterologous and truncated RNase P proteins in Bacillus subtilis. Mol Microbiol 66: 801-813.

Gruegelsiepe H, Willkomm DK, Goudinakis O, Hartmann RK. 2003. Antisense inhibition of Escherichia coli RNase P RNA: mechanistic aspects. Chembiochem 4: 1049-1056.

Gruegelsiepe H, Schön A, Kirsebom LA, Hartmann RK. 2005. Enzymatic RNA synthesis using bacteriophage T7 RNA polymerase. In Handbook of RNA Biochemistry (ed. Hartmann RK, et al.), pp. 3-21. Wiley-VCH Verlag GmbH \& Co. KGaA, Weinheim, Germany.

Gruegelsiepe H, Brandt O, Hartmann RK. 2006. Antisense inhibition of RNase P: mechanistic aspects and application to live bacteria. J Biol Chem 281: 30613-30620.

Haas ES, Brown JW, Pitulle C, Pace NR. 1994. Further perspectives on the catalytic core and secondary structure of ribonuclease P RNA. Proc Natl Acad Sci 91: 2527-2531.

Haas ES, Banta AB, Harris JK, Pace NR, Brown JW. 1996. Structure and evolution of ribonuclease P RNA in Gram-positive bacteria. Nucleic Acids Res 24: 4775-4782.

Hartmann RK, Gößringer M, Späth B, Fischer S, Marchfelder A. 2009. The making of tRNAs and more-RNase P and tRNase Z. Prog Mol Biol Transl Sci 85: 319-368.

Heide C, Feltens R, Hartmann RK. 2001. Purine N7 groups that are crucial to the interaction of Escherichia coli RNase P RNA with tRNA. RNA 7: 958-968.

Holzmann J, Frank P, Loffler E, Bennett KL, Gerner C, Rossmanith W. 2008. RNase P without RNA: identification and functional reconstitution of the human mitochondrial tRNA processing enzyme. Cell 135: 462-474.

Hori Y, Rogert MC, Tanaka T, Kikuchi Y, Bichenkova EV, Wilton AN, Gbaj A, Douglas KT. 2005. Porphyrins and porphines bind strongly and specifically to tRNA, precursor tRNA and to M1 RNA and inhibit the ribonuclease $\mathrm{P}$ ribozyme reaction. Biochim Biophys Acta 1730: 47-55.

Jarrous N, Gopalan V. 2010. Archaeal/Eukaryal RNase P: subunits, functions and RNA diversification. Nucleic Acids Res 38: 7885-7894.

Kawamoto SA, Sudhahar CG, Hatfield CL, Sun J, Berham EJ, Gopalan V. 2008. Studies on the mechanism of inhibition of bacterial ribonuclease $\mathrm{P}$ by aminoglycoside derivatives. Nucleic Acids Res 36: 697-704.

Kazantsev AV, Pace NR. 2006. Bacterial RNase P: a new view of an ancient enzyme. Nat Rev Microbiol 4: 729-740.

Kazantsev AV, Krivenko AA, Harrington DJ, Holbrook SR, Adams PD, Pace NR. 2005. Crystal structure of a bacterial ribonuclease P RNA. Proc Natl Acad Sci 102: 13392-13397.

Kazantsev AV, Rambo RP, Karimpour S, Santalucia J Jr, Tainer JA, Pace NR. 2011. Solution structure of RNase P RNA. RNA 17: 1159-1171.

Kikovska E, Svärd SG, Kirsebom LA. 2007. Eukaryotic RNase P RNA mediates cleavage in the absence of protein. Proc Natl Acad Sci 104: 2062-2067.

Kirsebom LA, Baer MF, Altman S. 1988. Differential effects of mutations in the protein and RNA moieties of RNase P on the efficiency of suppression by various tRNA suppressors. J Mol Biol 204: 879-888.

Krasilnikov AS, Yang X, Pan T, Mondragón A. 2003. Crystal structure of the specificity domain of ribonuclease P. Nature 421: 760-764.

Krasilnikov AS, Xiao Y, Pan T, Mondragón A. 2004. Basis for structural diversity in homologous RNAs. Science 306: 104-107.

Lai LB, Vioque A, Kirsebom LA, Gopalan V. 2010. Unexpected diversity of RNase P, an ancient tRNA processing enzyme: challenges and prospects. FEBS Lett 584: 287-296.

Lechner M, Rossmanith W, Hartmann RK, Thölken C, Gutmann B, Giegé P, Gobert A. 2015. Distribution of ribonucleoprotein and protein-only RNase P in Eukarya. Mol Biol Evol 32: 3186-3193.

Li D, Willkomm DK, Hartmann RK. 2009. Minor changes largely restore catalytic activity of archaeal RNase P RNA from Methanothermobacter thermoautotrophicus. Nucleic Acids Res 37: 231-242. 
Li D, Gössringer M, Hartmann RK. 2011. Archaeal-bacterial chimeric RNase P RNAs: towards understanding RNA's architecture, function and evolution. Chembiochem 12: 1536-1543.

Liu X, Chen Y, Fierke CA. 2014. A real-time fluorescence polarization activity assay to screen for inhibitors of bacterial ribonuclease P. Nucleic Acids Res 42: e159.

Loria A, Pan T. 1996. Domain structure of the ribozyme from eubacterial ribonuclease P. RNA 2: 551-563.

Marszalkowski M, Teune JH, Steger G, Hartmann RK, Willkomm DK. 2006. Thermostable RNase P RNAs lacking P18 identified in the Aquificales. RNA 12: 1915-1921.

Marszalkowski M, Willkomm DK, Hartmann RK. 2008. Structural basis of a ribozyme's thermostability: P1-L9 interdomain interaction in RNase P RNA. RNA 14: 127-133.

Massire C, Jaeger L, Westhof E. 1997. Phylogenetic evidence for a new tertiary interaction in bacterial RNase P RNAs. RNA 3: 553-556.

Massire C, Jaeger L, Westhof E. 1998. Derivation of the three-dimensional architecture of bacterial ribonuclease P RNAs from comparative sequence analysis. J Mol Biol 279: 773-793.

Mikkelsen NE, Brannvall M, Virtanen A, Kirsebom LA. 1999. Inhibition of RNase P RNA cleavage by aminoglycosides. Proc Natl Acad Sci 96: 6155-6160.

Niranjanakumari S, Kurz JC, Fierke CA. 1998. Expression, purification and characterization of the recombinant ribonuclease $\mathrm{P}$ protein component from Bacillus subtilis. Nucleic Acids Res 26: 3090-3096.

Pannucci JA, Haas ES, Hall TA, Harris JK, Brown JW. 1999. RNase P RNAs from some Archaea are catalytically active. Proc Natl Acad Sci 96: 7803-7808.

Reiter NJ, Osterman A, Torres-Larios A, Swinger KK, Pan T, Mondragón A. 2010. Structure of a bacterial ribonuclease P holoenzyme in complex with tRNA. Nature 468: 784-789.

Schedl P, Primakoff P, Roberts J. 1974. Processing of E. coli tRNA precursors. Brookhaven Symp Biol 26: 53-76.
Svärd SG, Mattsson JG, Johansson KE, Kirsebom LA. 1994. Cloning and characterization of the RNase P RNA genes from two porcine mycoplasmas. Mol Microbiol 11: 849-859.

Svärd SG, Kagardt U, Kirsebom LA. 1996. Phylogenetic comparative mutational analysis of the base-pairing between RNase P RNA and its substrate. RNA 2: 463-472.

Torres-Larios A, Swinger KK, Krasilnikov AS, Pan T, Mondragón A. 2005. Crystal structure of the RNA component of bacterial ribonuclease P. Nature 437: 584-587.

Toumpeki C, Vourekas A, Kalavrizioti D, Stamatopoulou V, Drainas D. 2008. Activation of bacterial ribonuclease $\mathrm{P}$ by macrolides. Biochemistry 47: 4112-4118.

Vioque A. 1989. Protein synthesis inhibitors and catalytic RNA. Effect of puromycin on tRNA precursor processing by the RNA component of Escherichia coli RNase P. FEBS Lett 246: 137-139.

Walker SC, Marvin MC, Engelke DR. 2010. Eukaryote RNase P and RNase MRP. In Ribonuclease $P$, protein reviews (ed. Liu F, Altman S), Vol. 10, pp. 173-202. Springer, New York.

Warnecke JM, Held R, Busch S, Hartmann RK. 1999. Role of metal ions in the hydrolysis reaction catalyzed by RNase P RNA from Bacillus subtilis. J Mol Biol 290: 433-445.

Wegscheid B, Hartmann RK. 2006. The precursor tRNA 3'-CCA interaction with Escherichia coli RNase P RNA is essential for catalysis by RNase $\mathrm{P}$ in vivo. RNA 12: 2135-2148.

Wegscheid B, Hartmann RK. 2007. In vivo and in vitro investigation of bacterial type B RNase P interaction with tRNA 3'-CCA. Nucleic Acids Res 35: 2060-2073.

Willkomm DK, Gruegelsiepe H, Goudinakis O, Kretschmer-Kazemi Far R, Bald R, Erdmann VA, Hartmann RK. 2003. Evaluation of bacterial RNase P RNA as a drug target. Chembiochem 4: 1041-1048.

Willkomm DK, Pfeffer P, Reuter K, Klebe G, Hartmann RK. 2010. RNase P as a drug target. In Ribonuclease P (ed. Liu F, Altman S), Vol. 10, pp. 235-256. Springer, New York. 

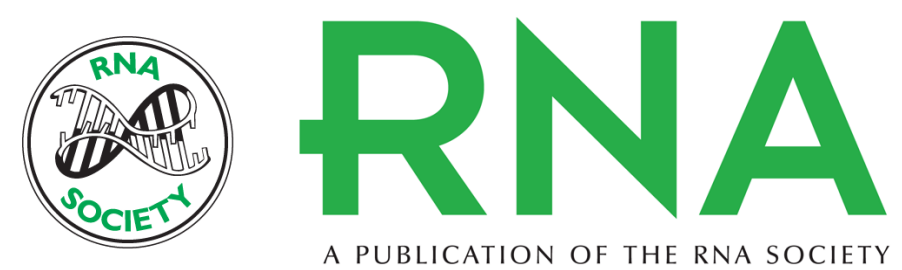

\section{Bacterial type B RNase P: functional characterization of the L5.1-L15.1 tertiary contact and antisense inhibition}

Dennis Walczyk, Dagmar K. Willkomm and Roland K. Hartmann

RNA 2016 22: 1699-1709 originally published online September 7, 2016

Access the most recent version at doi:10.1261/rna.057422.116

\section{Supplemental} Material

References

Creative Commons

License

Email Alerting
Service
http://rnajournal.cshlp.org/content/suppl/2016/09/07/rna.057422.116.DC1

This article cites 54 articles, 17 of which can be accessed free at: http://rnajournal.cshlp.org/content/22/11/1699.full.htmI\#ref-list-1

This article is distributed exclusively by the RNA Society for the first 12 months after the full-issue publication date (see http://rnajournal.cshlp.org/site/misc/terms.xhtml). After 12 months, it is available under a Creative Commons License (Attribution-NonCommercial 4.0 International), as described at http://creativecommons.org/licenses/by-nc/4.0/.

Receive free email alerts when new articles cite this article - sign up in the box at the top right corner of the article or click here.

To subscribe to RNA go to:

http://rnajournal.cshlp.org/subscriptions 